\title{
The spirituality and spiritual care of clinical nurses in Indonesia
}

\author{
Rosnancy Renolita Sinaga ${ }^{1}$, Donald Loffie Muntu ${ }^{2}$, Sedia Simbolon ${ }^{3}$, Sri Susanty ${ }^{4}$ \\ ${ }^{1,3}$ Akademi Keperawatan Surya Nusantara, Indonesia \\ ${ }^{2}$ Sekolah Tinggi Filsafat Teologia Surya Nusantara, Indonesia \\ ${ }^{4}$ Nursing Study Program, Faculty of Medicine, Universitas Halu Oleo, Indonesia
}

\section{Article Info}

Article history:

Received Feb 24, 2021

Revised Jun 5, 2021

Accepted Jun 20, 2021

\section{Keywords:}

Clinical nurses

Indonesia

Spiritual care

Spirituality

\begin{abstract}
This study aimed to investigate associated factors of spirituality and spiritual care in clinical nurses in Indonesia. Cross-sectional descriptive and correlational research designs were used in this study. Purposive sampling was applied among 204 participants in private hospitals, Medan and Bandung, Indonesia. The questionnaires consisted of demographic and characteristics information and the spirituality and spiritual care rating scale (SSCRS). Mann Whitney test was used to investigate associated factors of spirituality and spiritual care in clinical nurses in Indonesia. This study found that there was statistically significant between department with spirituality $(\mathrm{p}=0.017)$, receiving spiritual care lessons during nurse training with spiritual care $(\mathrm{p}=0.032)$, and receiving spiritual care lessons during nurse training $(\mathrm{p}=0.013)$ and educational background with nurses' perception of spirituality and spiritual care $(\mathrm{p}=0.040)$. Receiving spiritual care lessons during nurse training, and educational background were statistically significant with spirituality and spiritual care in clinical nurses in Indonesia. The findings of this study provide information for clinical nurses and generally of nurses to understand the perception of spirituality and spiritual care in hospital for care patient in a hospital in Indonesia. It is also suggested that appropriate strategies to improve knowledge and perception of spirituality and spiritual care should be developed shortly.
\end{abstract}

This is an open access article under the CC BY-SA license.

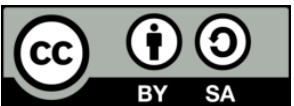

\section{Corresponding Author:}

Sri Susanty

Nursing Study Program, Faculty of Medicine

Universitas Halu Oleo

Kampus Hijau Bumi Tridharma Anduonohu, Kendari City, 93132, Southeast Sulawesi Indonesia

Email: sri.susanty@uho.ac.id

\section{INTRODUCTION}

Spirituality has a broad basic concept with many points of view. The search for identity usually involves the values of spirituality in a broad sense. Subjectively, spirituality is very difficult to define [1]. Spirituality is a personal experience of each human being that indirectly slaughteres all of us. Spiritual experiences are described as something sacred and transcendent which has a profound essence. Culture, ethnic background, religion, level of education, and clinical experience are factors that shape the spirituality of nurses [2]-[4]. Nurses' perceptions of spirituality and spiritual care greatly affect their ability to provide spiritual care, especially in providing consistent quality nursing care [5]-[7]. Thus, the existence of spiritual care is an activity and procedure that is used as an improvement of the patient's spiritual well-being. This is done in a constructive manner professional care relationship between nurses and patients, this professional relationship building strategy is carried out by building interpersonal relationships between nurses and patients [8], [9]. The positive effect on the patient's stress response can be reduced by spiritual treatment. Among other things, spiritual well-being is a balance between the physical, psychosocial, and spiritual 
aspects of oneself, as well as a sense of integrity and excellence, and interpersonal relationships can also be built through spirituality care provided by nurses. Nurses can also apply spiritual nursing practice [10].

Spiritual care has two types of practice patterns which include the category of religious intervention and the category of non-religious intervention. What nurses can do in providing religious intervention is by providing spiritual care according to the patient's religious beliefs, as well as providing opportunities for patients to be closer to God. Another thing that can be done is by expressing their values and beliefs, giving them the opportunity to practice their religion, and giving them references to religious leaders and religious leaders whom the patient embraces. Nurses can also provide non-religious interventions to patients by providing mental support by providing opportunities for the family to accompany, communicate and encourage the patient, sympathize with the patient and their family, pay attention, and have a sincere sense of the patient [11]. Despite the importance of spiritual care, nurses have expressed a need to learn how to provide spiritual care. Integrating spiritual care into nursing curricula could meet that need during the nurse formation process [12]. Previous studies have reported related demographic and characteristics factor such as a nurse's gender, religion, experience, carrier, and education level to individual perceptions of spirituality and spiritual care [13]-[15].

Globally, several studies have provided valuable insight into the range of nurse perceptions of spirituality and spiritual care. As we have known, there are a limited number of studies conducted on spirituality and spiritual care in Indonesia. Furthermore, this study aimed to investigate associated factors of spirituality and spiritual care in clinical nurses in Indonesia.

\section{RESEARCH METHOD}

\subsection{Data collection procedure}

After obtaining institutional approval, eligible participants in each department were randomly selected using a computer. The researcher explained the purpose of the study, collection procedures, benefits, and risks. The researchers referred to the research environment, explained the purpose of the study in a meeting with nurses, and confirmed the results' confidentiality following obtaining the required permits from the hospital nursing administrator. After completing the questionnaires, the participants placed the questionnaires in a sealed box by themselves. A participant returning the questionnaires indicated that they agreed to take part in the study. The data collection period was between august and September 2019.

\subsection{Instruments}

The questionnaires consisted of two parts: Socio-demographic and characteristics information; the spirituality and spiritual care rating scale (SSCRS). Socio-demographic factors included age, gender, marital status, educational background; characteristics information factors included length of clinical experience (years), department, and receiving spiritual care lesson during nurse training.

The spirituality and spiritual care rating scale (SSCRS) developed by McSherry et al. [16] was used to assess individual perceptio. The Indonesian version of the SSCRS was applied in this study by Herlianita et al. [17] The instrument consists of 17 items, five items ( $, \mathrm{b}, \mathrm{g}, \mathrm{k}$, and $\mathrm{n}$ ) represent spiritual care, and 12 last represent spirituality. A higher score indicates a greater level of perceived spirituality of participants. The validity of the original 17-item SSCRS was analyzed using principal component analysis (PCA) with varimax rotation. The content validity index was 0.92 . The internal consistency (Cronbach's a) ranged between 0.80 and 0.85 [16], [18]

\subsection{Data analysis}

IBM statistical package for the social science (SPSS) for Windows, version. 25.0 (IBM Corp. Armonk, NY) was used to analyze the data. Demographic characteristic of respondents was described using percentage for categorical data to show univariate analysis as age, gender, marital status, educational background, length of clinical experience (years), department, and receiving spiritual care lesson during nurse training. MannWhitney test was used to investigate associated factors of spirituality and spiritual care. Statistical significance was accepted at $\mathrm{p}<0.05$.

\subsection{Ethical considerations}

The ethical approval was obtained from the Research and Community Committee of the Hospital (No. 026/DIKLAT/RSAM/IX/2019). Permission for conducting this study was obtained from the management of the hospital "Rumah Sakit Advent Medan". Nurses clinical who refused or withdrew from the study had no penalties. This study caused no physical or psychological harm to participants. 


\section{RESULTS AND DISCUSSION}

\subsection{Demographic characteristics of study participants}

Among the 204 participants, 38 (18.6\%) were male, and $166(81.4 \%)$ were female. They were followed by 27-35 years, 18-26 years, and more than 45 . The majority of nurses' clinics with married status are $65.2 \%$ marriage, $33.3 \%$ single, and $1.5 \%$ divorce. Their educational backgrounds are $56.4 \%$ bachelor, 40.2\% diploma, and 3.4\% magister. Their clinical experience length is more than ten years (52\%) and less than ten years (48\%). More of them are working in other departments and followed by the medical/surgical department, emergency department, pediatric department, intensive care unit (ICU) department, and the operating room (OR) department. Almost all of them are no receiving spiritual care lessons during nurse training as shown in Table 1.

Table 1. Socio-demography of respondents $(n=204)$

\begin{tabular}{lcc}
\hline \multicolumn{1}{c}{ Variable } & Frequency & Percentage \\
\hline Gender & 38 & \\
Man & 166 & 81.4 \\
Women & & \\
Age (years) & 42 & 20.6 \\
18-26 & 61 & 29.9 \\
$27-35$ & 70 & 34.3 \\
$36-44$ & 31 & 15.2 \\
>45 & & \\
Marital status & 3 & 1.5 \\
Divorce & 133 & 65.2 \\
Marriage & 68 & 33.3 \\
Single & & \\
Educational background & 82 & 40.2 \\
Diploma & 155 & 56.4 \\
Bachelor & 7 & 3.4 \\
Magister & & \\
Length of clinical experience (years) & 98 & 48 \\
$\quad$ <10 & 106 & 52 \\
>10 & & \\
Department & 38 & 18.6 \\
Emergency & 8 & 3.9 \\
ICU & 67 & 32.8 \\
Medical/surgical & 4 & 2 \\
OR & 17 & 8.3 \\
Pediatric & 70 & 34.3 \\
Others & & \\
Receiving spiritual care lessons during nurse training & 18 & 8.8 \\
Ever & 186 & 91.2 \\
Never & & \\
\hline Note ICU: inter & &
\end{tabular}

Note; ICU: intensive care unit; OR: operating room

\subsection{Association factors of spirituality and spiritual care on clinical nurses in Indonesia}

There was a statistically significant between department with spirituality $(p=0.017)$, receiving spiritual care lessons during nurse training with spiritual care $(\mathrm{p}=0.032)$, and receiving spiritual care lessons during nurse training $(\mathrm{p}=0.013)$ and educational background $(\mathrm{p}=0.040)$ with spirituality and spiritual care. The detail of item score explained in the Table 2. The Associated factors of spirituality and spiritual care in Indonesia as shown in Table 3.

Table 2. Scale means scores of the nurses

\begin{tabular}{lc}
\hline \multicolumn{1}{c}{ Subscale } & Item mean score of scale (Mean \pm sd) \\
\hline Spirituality & $4.41 \pm 0.52(22.07 \pm 2.61)$ \\
Spiritual care & $3.48 \pm 0.45(41.77 \pm 5.35)$ \\
Spirituality and spiritual care & $3.76 \pm 0.41(63.84 \pm 6.99)$ \\
\hline
\end{tabular}

\subsection{Spirituality and spiritual care}

All nurses had shown their perception and spirituality and spiritual care. They strongly agreed that nurses should bring morals and religion into service, provided spiritual care and support, and gave good experience, and made their patients have to hope to heal. Based on Table 4, more than $60 \%$ participants have strongly agreed that nurses could provide spiritual care by showing kindness, concern, and cheerfulness when 
giving care. Nevertheless, participants have strongly disagreed when nurses can provide spiritual care by having respect for privacy, dignity. The detail of spirituality and spiritual care are shown in Table 4 .

Table 3. Associated factors of spirituality and spiritual care in Indonesia

\begin{tabular}{|c|c|c|c|c|c|c|c|c|c|c|c|c|}
\hline \multirow[b]{2}{*}{ Independent Variable } & \multicolumn{5}{|c|}{ Spirituality } & \multicolumn{3}{|c|}{ Spiritual care } & \multicolumn{4}{|c|}{ Spirituality and spiritual care } \\
\hline & $\mathrm{N}$ & $\begin{array}{l}\text { Mean } \\
\text { rank }\end{array}$ & $\mathrm{Z}$ & $\mathrm{p}$ & $\mathrm{N}$ & $\begin{array}{l}\text { Mean } \\
\text { rank }\end{array}$ & $\mathrm{Z}$ & $\mathrm{p}$ & $\mathrm{N}$ & $\begin{array}{l}\text { Mean } \\
\text { rank }\end{array}$ & Z & $\mathrm{p}$ \\
\hline Department & & & & 0.017 & & & & & & & & \\
\hline $\begin{array}{l}\text { Emergency - ICU - } \\
\text { Medical/surgical }\end{array}$ & 79 & 91.86 & 2.377 & & & & & & & & & \\
\hline OR - Paediatric - Others & 125 & 109.22 & & & & & & & & & & \\
\hline Receiving Spiritual Care & & & & & & & & 0.032 & & & & 0.013 \\
\hline Lessons During Nurse & & & & & & & 2.143 & & & & 2.482 & \\
\hline Training & & & & & & & & & & & & \\
\hline Ever & & & & & 6 & 108 & & & 5 & 82.30 & & \\
\hline Never & & & & & 198 & 102.33 & & & 199 & 103.01 & & \\
\hline Educational Background & & & & & & & & & & & & 0.040 \\
\hline Diploma & & & & & & & & & 5 & 119.40 & 2.056 & \\
\hline Bachelor - magister & & & & & & & & & 199 & 102.08 & & \\
\hline
\end{tabular}

Table 4. Frequency and percentage of SSCR questionnaire $(n=204)$

\begin{tabular}{|c|c|c|c|c|c|}
\hline Spirituality and spiritual care rating scale items & $\begin{array}{l}\text { Strongly disagree } \\
\text { (frequency, \%) }\end{array}$ & $\begin{array}{l}\text { Disagree } \\
\text { (frequency, } \\
\% \text { ) }\end{array}$ & $\begin{array}{l}\text { Neither agree } \\
\text { nor disagree } \\
\text { (frequency, } \\
\% \text { ) }\end{array}$ & $\begin{array}{c}\text { Agree } \\
\text { (frequency, } \\
\% \text { ) }\end{array}$ & $\begin{array}{l}\text { Strongly } \\
\text { agree } \\
\text { (frequency, } \\
\% \text { ) }\end{array}$ \\
\hline $\begin{array}{l}\text { 1. I believe nurses can provide spiritual care by } \\
\text { arranging a patient's religious leader's visit if } \\
\text { requested. }\end{array}$ & $5(2.5)$ & $7(3.4)$ & $7(3.4)$ & $90(44.1)$ & $95(46.6)$ \\
\hline $\begin{array}{l}\text { 2. I believe nurses can provide spiritual care by } \\
\text { showing kindness, concern, and cheerfulness } \\
\text { when giving care }\end{array}$ & $1(0.5)$ & $1(0.5)$ & $3(1.5)$ & $64(31.4)$ & $135(66.2)$ \\
\hline $\begin{array}{l}\text { 3. I believe spirituality is concerned with a } \\
\text { need to forgive and need to be forgiven }\end{array}$ & $6(2.9)$ & $5(2.5)$ & $10(4.9)$ & $91(44.6)$ & $92(45.1)$ \\
\hline $\begin{array}{l}\text { 4. I believe spirituality involves only going to a } \\
\text { place of worship }\end{array}$ & $84(41.2)$ & $82(40.2)$ & $16(7.8)$ & $12(5.9)$ & $10(4.9)$ \\
\hline $\begin{array}{l}\text { 5. I believe spirituality is not concerned with } \\
\text { our believes and faith }\end{array}$ & $81(39.7)$ & $75(36.8)$ & $26(12.7)$ & $14(6.9)$ & $8(3.9)$ \\
\hline $\begin{array}{l}\text { 6. I believe spirituality is about finding } \\
\text { meaning in the good and bad events of life }\end{array}$ & $7(3.4)$ & $29(14.2)$ & $35(17.2)$ & $99(48.5)$ & $34(16.7)$ \\
\hline $\begin{array}{l}\text { 7. I believe nurses can provide spiritual care by } \\
\text { spending time with a patient, giving support } \\
\text { and reassurance, especially in time of need }\end{array}$ & $2(1)$ & $1(0.5)$ & $13(6.4)$ & $101(49.5)$ & $87(42.6)$ \\
\hline $\begin{array}{l}\text { 8. I believe nurses can provide spiritual care by } \\
\text { enabling a patient to find meaning and } \\
\text { purpose in their illness }\end{array}$ & $7(3.4)$ & $4(2)$ & $31(15.2)$ & $103(50.5)$ & 59 (28.9) \\
\hline $\begin{array}{l}\text { 9. I believe spirituality is about having a sense } \\
\text { of hope in life }\end{array}$ & $2(1)$ & $2(1)$ & $10(4.9)$ & $94(46.1)$ & $96(47.1)$ \\
\hline $\begin{array}{l}\text { 10. I believe spirituality is to do with the way } \\
\text { one conducts one's life here and now }\end{array}$ & $3(1.5)$ & $26(12.7)$ & 44 (21.6) & $94(46.1)$ & 37 (18.1) \\
\hline $\begin{array}{l}\text { 11. I believe nurses can provide spiritual care by } \\
\text { listening to patients and allow time to discuss } \\
\text { and explore their fears, anxieties, and troubles }\end{array}$ & $2(1)$ & $2(1)$ & $5(2.5)$ & 109 (53.4) & $86(42.2)$ \\
\hline $\begin{array}{l}\text { 12. I believe spirituality is a unifying force that } \\
\text { enables one to be at peace with oneself and } \\
\text { the world }\end{array}$ & $2(1)$ & $5(2.5)$ & $20(9.8)$ & $106(52)$ & $71(34.8)$ \\
\hline $\begin{array}{l}\text { 13. I believe spirituality does not include areas } \\
\text { such as art, creativity, and self-expression }\end{array}$ & $22(10.8)$ & 61 (29.9) & 64 (31.4) & $42(20.6)$ & $15(7.4)$ \\
\hline $\begin{array}{l}\text { 14. I believe nurses can provide spiritual care by } \\
\text { having respect for privacy, dignity, and } \\
\text { religious and cultural beliefs of a patient }\end{array}$ & $1(0.5)$ & $0(0)$ & $4(2)$ & $90(44.1)$ & $109(53.4)$ \\
\hline $\begin{array}{l}\text { 15. I believe spirituality involves personal } \\
\text { friendships and relationships }\end{array}$ & $2(1)$ & $8(3.9)$ & $20(9.8)$ & $107(52.5)$ & $67(32.8)$ \\
\hline $\begin{array}{l}\text { 16. I believe spirituality does not apply to all } \\
\text { religions }\end{array}$ & $43(21.1)$ & $72(35.3)$ & $37(18.1)$ & $36(17.6)$ & $16(7.8)$ \\
\hline $\begin{array}{l}\text { 17. I believe spirituality includes people's } \\
\text { morals }\end{array}$ & $2(1)$ & $3(1.5)$ & $14(6.9)$ & $106(52)$ & 79 (38.7) \\
\hline
\end{tabular}


This study aimed to evaluate spirituality and spiritual care in clinical nurses in Indonesia. The result showed a difference significant between departments with spirituality $(\mathrm{p}=0.017)$. Previous research found the same result that had associated working in medical departments with spirituality and spiritual care $(\mathrm{p}=<0.05)$ [19]. Chew's research used general linear model found that clinical practice area as medical/surgical, endoscopy, and emergency had significant different with spirituality and spiritual care $(\mathrm{f}=3.775, \mathrm{p}=0.005)$ [15]. Another research found that the health care sector had significant differences with spirituality and spiritual care $(\mathrm{f}=3.28, \mathrm{p}=0.021)$ [20].

Receiving spiritual care lessons during nurse training had significant different with spiritual care $(\mathrm{p}=0.032)$ and spirituality and spiritual care $(\mathrm{p}=0.013)$. Previous research found the same result that had significant between received educations in spiritual care with spirituality and spiritual care $(p=<0.001)[19]$. Another research found that nurses have no desire to spiritual care training had relationship with spiritual care $(\mathrm{OR}=5.00,95 \% \mathrm{CI}=1.82-12.50, \mathrm{p}=0.002)[21]$.

Education had significant with spirituality and spiritual care (p-value: 0.040). Previous research found the same result that had significant between educations with spirituality and spiritual care (p: $<0.001)$ [22]. Another study found that education background had a significant difference between spirituality and spiritual care $(\mathrm{f}=5.024, \mathrm{p}=0.002)$ [23].

Humans are multidimensional entities created by God. Humans have various aspects of life that support our noble values, aspects that they have include physical, psychological, social, and spiritual aspects. Improving health and coordinating with other dimensions are the essence of spirituality [24]. Health is defined by the World Health Organization as "a state of complete physical, mental, and social well-being". This definition clearly distinguishes three domains that incorporate one's well-being. Physical health status is often used to define the health status where disease symptoms, functional limitation, and pain will decrease overall health [25]-[27]. Physical health can be influenced by the concept of thinking that the most important thing in maintaining health is only through physical health and a lack of appreciation for how direct spiritual health is [28].

A nurse is a person who has been prepared and given the authority to provide care in general nursing practice and to carry out health promotion, in order to prevent disease. Nurses are also authorized to care for physically and mentally sick people, as well as people with disabilities, this has been stated by the International Council of Nurses. It has also been advised by the World Health Organization that the physical, psychological, social, and spiritual well-being of patients is more important than focusing on the patient's illness [29], [30]. Today, spiritual care is considered an essential part of the overall care provided to improve patients and their families [31], [32]. Moreover, nurses' perceptions and understanding are very influencing readiness of nurses in providing spiritual care to patients. So the importance of preparation about spirituality and spiritual care. Previous research related to nurses' perceptions of spirituality and spiritual care found that nurses who had a better understanding of the meaning of spirituality were better able to provide spiritual care to patients [33], [34]. Spirituality has associated with character strength that can be supported to develop positive human aspects [35].

We acknowledge that the limitation was derived cross-sectional study where the condition face covid-19 pandemic was limited to exploring more. Some essential data had no available at baseline as religion, family influence, community influence, and mental health. Longitudinal research is needed to explore more variables to find the most factors that have conclusive significance with nurses' perception and spirituality and spiritual care.

\section{CONCLUSION}

Departments, education background, and receiving spiritual care lessons during nurse training were three factors that had significance with spirituality and spiritual care. The head of nurses should pay attention to these things because these variables impacted service care and patients' satisfaction. Providing education as training is one of the best strategies to improve knowledge and perception of spirituality and spiritual care.

\section{REFERENCES}

[1] D. Villani, A. Sorgente, P. Iannello, and A. Antonietti, "The Role of Spirituality and Religiosity in Subjective WellBeing of Individuals With Different Religious Status," Front. Psychol., vol. 10, no. 6, pp. 1-11, 2019, doi: 10.3389/fpsyg.2019.01525.

[2] R. Harrad, C. Cosentino, R. Keasley, and F. Sulla, "Spiritual care in nursing: an overview of the measures used to assess spiritual care provision and related factors amongst nurses," Acta Biomed Heal. Prof., vol. 90, no. 4, pp. 4455, 2019, doi: 10.23750/abm.v90i4-S.8300.

[3] Q. C. Msn et al., "Spiritual care competence and its relationship with self-efficacy: An online survey among nurses in mainland China," J. Nurs. Manag, vol. 29, no. 2, pp. 326-332, 2020, doi: 10.1111/jonm.13157. 
[4] S. Rahman, H. Elbi, A. C. Cetinkaya, S. Altan, E. Ozan, and E. Pirincci, "Factors that predict the perception of spirituality and spiritual care of nurses working in high-risk units and the effect of death anxiety," Perspect. Psychiatr. Care, vol. 24, no. 3, pp. 1-8, 2020, doi: 10.1111/ppc.12651.

[5] N. Akansel and R. Watson, "Nurses ' perceptions of caring activities in nursing," Nurs. Open, vol. 00, no. 9, pp. 111, 2020, doi: 10.1002/nop2.653.

[6] I. De Barbieri et al., "Relationship-based care model in paediatrics : A randomized controlled trial to implement the parents ' perception of the quality of nursing care," J. Adv. Nurs., vol. 76, no. 8, pp. 3597-3608, 2020, doi: 10.1111/jan.14585.

[7] A. F. Rn et al., "Nurses ' perception of implicit nursing care rationing in Croatia-A cross-sectional multicentre study," J. Nurs. Manag, vol. 11, no. 3, pp. 1-10, 2020, doi: 10.1111/jonm.13002.

[8] M. R. Rn and D. Care, "Perceptions of inpatients and nurses towards the importance of nurses' caring behaviours in rehabilitation : A comparative study," Int. J. Nurs. Pract., vol. 21, no. 5, pp. 1-9, 2020, doi: 10.1111/ijn.12835.

[9] R. Van Leeuwen et al., "The development of a consensus-based spiritual care education standard for undergraduate nursing and midwifery students:An educational mixed methods study," JAN - Lead. Glob. Nurs. Res., vol. 14, no. 6, pp. 1-14, 2020, doi: 10.1111/jan.14613.

[10] Y. Héliot, C. Rojon, I. H. Gleibs, A. Coyle, and D. M. Rousseau, "Religious identity in the workplace: A systematic review, research agenda, and practical implications," Hum. Resour. Manag., vol. 1, no. 1, pp. 1-21, 2019, doi: 10.1002/hrm.21983.

[11] S. Reimer and K. Rn, "Complicating nursing's views on religion and politics in healthcare," Nurs. Philos., vol. 20, no. 6, pp. 1-10, 2019, doi: 10.1111/nup.12282.

[12] S. Hsieh et al., "Factors associated with spiritual care competencies in Taiwan's clinical nurses: A descriptive correlational study," J. Clin. Nurs., vol. 29, no. 5, pp. 1599-1613, 2020, doi: 10.1111/jocn.15141.

[13] K. L. Cooper, L. Luck, E. Chang, and K. Dixon, "What is the practice of spiritual care? A critical discourse analysis of registered nurses' understanding of spirituality," Nurs. Inq., vol. 12, no. 9, pp. 1-10, 2020, doi: 10.1111/nin.12385.

[14] S. Gautam, S. Neville, and J. Montayre, "What is known about the spirituality in older adults living in residential care facilities? An Integrative review," Int. J. Older People Nurs., vol. 17, no. 1, pp. 1-12, 2019, doi: 10.1111/opn.12228.

[15] B. W. K. Chew, L. H. Tiew, and D. K. Creedy, "Acute care nurses ' perceptions of spirituality and spiritual care : an exploratory study in Singapore," J. Clin. Nurs., pp. 1-8, 2016, doi: 10.1111/jocn.13290.

[16] McSherry, and Jamieson, "An online survey of nurses' perceptions of spirituality and spiritual care," Journal of Clinical Nursing, vol. 20, pp. 1757-1767, 2011.

[17] R. Herlianita, M. Yen, S. J. Fetzer, and E. C. Lin, "Perception of Spirituality and Spiritual Care among Muslim Nurses in Indonesia," J. Relig. Health, vol. 57, no. 2, pp. 762-773, doi: 10.1007/s10943-017-0437-6.

[18] M. F. Khoshknab, M. Mazaheri, S. S. B. Maddah, and M. Rahgozar, "Validation and Reliability Test of Persian Version of The Spirituality and Spiritual Care Rating Scale (SSCRS)," J. Clin. Nurs., vol. 19, no. 6, pp. 2939-2941, 2010, doi: 10.1111/j.1365-2702.2010.03411.x.

[19] Z. A. Şahin and F. K. Özdemir, "Spirituality and spiritual care: a descriptive survey of nursing practices in Turkey," Contemp. Nurse, vol. 52, no. 4, pp. 454-461, 2016, doi: 10.1080/10376178.2016.1221324.

[20] G. Ahmad et al., "Nurses' Perceptions of Spirituality and Spiritual Care Giving: A Comparison Study Among All Health Care Sectors in Jordan," Indian J. Palliat. Care, vol. 22, no. 1, pp. 42-49, 2021, doi: 10.4103/09731075.173949.

[21] M. Balboni and J. Peteet, "The Relationship between Medicine, Spirituality and Religion: Three Models for Integration The Relationship between Medicine, Spirituality and Religion: Three Models for Integration," J Reli. Heal., vol. 53, no. 6, pp. 1586-1598, 2014, doi: 10.1007/s10943-014-9901-8.

[22] F. Ozbasaran, S. Ergul, A. B. Temel, G. G. Aslan, and A. Coban, "Turkish nurses' perceptions of spirituality and spiritual care Turkish nurses 'perceptions of spirituality and spiritual care," J. Clin. Nurs., vol. 1, no. 7, pp. 1-9, 2011, doi: 10.1111/j.1365-2702.2011.03778.x.

[23] M. A. Atarhim, S. Lee, and B. Copnell, "An Exploratory Study of Spirituality and Spiritual Care Among Malaysian Nurses,” J. Relig. Health, vol. 58, no. 1, pp. 180-194, 2019, doi: 10.1007/s10943-018-0624-0.

[24] K. a Frass and H. Al Harazi, "Outcome of vaginal birth after caesarean section in women with one previous section and spontaneous onset of labour.," Emhj, vol. 17, no. 8, pp. 646-50, 2011.

[25] A. Bożek, P. F. Nowak, and M. Blukacz, "The Relationship Between Spirituality, Health-Related Behavior, and Psychological Well-Being," Front. Psychol., vol. 11, no. 8, pp. 1-13, 2020, doi: 10.3389/fpsyg.2020.01997.

[26] A. Ghaderi, S. M. Tabatabaei, S. Nedjat, M. Javadi, and B. Larijani, "Explanatory definition of the concept of spiritual health: A qualitative study in Iran," J. Med. Ethics Hist. Med., vol. 11, no. 3, pp. 1-7, 2018.

[27] M. Nagase, "Does a Multi-Dimensional Concept of Health Include Spirituality? Analysis of Japan Health Science Council's Discussionson WHO's 'Definition of Health' (1998),' Int. J. Appl. Sociol., vol. 2, no. 6, pp. 71-77, 2012, doi: $10.5923 /$ j.ijas.20120206.03.

[28] A. R. Naftali, Y. Y. Ranimpi, and M. A. Anwar, "Spiritual health and elderly readiness in facing death," Bul. Psikol., vol. 25, no. 2, pp. 124-135, 2017, doi: 10.22146/buletinpsikologi.28992.

[29] B. Kaddourah, A. Abu-Shaheen, and M. Al-Tannir, "Nurses' perceptions of spirituality and spiritual care at five tertiary care hospitals in Riyadh, Saudi Arabia: A cross-sectional study," Oman Med. J., vol. 33, no. 2, pp. 154-158, 2018, doi: 10.5001/omj.2018.28.

[30] N. Cockell and W. Mcsherry, "Spiritual care in nursing: An overview of published international research," J. Nurs. 
Manag., vol. 20, no. 8, pp. 958-969, 2012, doi: 10.1111/j.1365-2834.2012.01450.x.

[31] P. M. Vigna, I. De Castro, and R. R. L. Fumis, "Spirituality alleviates the burden on family members caring for patients receiving palliative care exclusively," BMC Palliat. Care, vol. 19, no. 1, pp. 1-8, 2020, doi: 10.1186/s12904-020-00585-2.

[32] G. D. Heinke, S. Borchert, A. Young, and E. Wagner, "Quality of Spiritual Care at the End of Life: What the Family Expects for Their Loved One," J. Health Care Chaplain., vol. 26, no. 4, pp. 159-174, 2020, doi: 10.1080/08854726.2019.1644816.

[33] M. Neathery, E. J. Taylor, and Z. He, "Perceived barriers to providing spiritual care among psychiatric mental health nurses," Arch. Psychiatr. Nurs., vol. 34, no. 6, pp. 572-579, 2020, doi: 10.1016/j.apnu.2020.10.004.

[34] M. Neathery, Z. He, E. J. Taylor, and B. Deal, "Spiritual Perspectives, Spiritual Care, and Knowledge of Recovery Among Psychiatric Mental Health Nurses," J. Am. Psychiatr. Nurses Assoc., vol. 26, no. 4, pp. 364-372, 2020, doi: $10.1177 / 1078390319846548$

[35] A. Kor, S. Pirutinsky, M. Mikulincer, A. Shoshani, and L. Miller, "A longitudinal study of spirituality, character strengths, subjective well-being, and prosociality in middle school adolescents," Front. Psychol., vol. 10, no. FEB, pp. 1-12, 2019, doi: 10.3389/fpsyg.2019.00377. 